\title{
РЕАЛІЗАЦІЯ ПРОСКТНОЇ ТЕХНОЛОГІЇ НАВЧАННЯ В СИСТЕМІ ПОЗАШКІЛЬНОЇ ОСВІТИ
}

\author{
Надія Вовк \\ кандидат педагогічних наук, доцент, \\ доцент кафедри теорії і практики технологічної та професійної освіти \\ ДВНЗ «Донбаський державний педагогічний університет» \\ м. Слов’янськ, Україна \\ nadiyavovk@ukr.net \\ Ірина Вікторенко \\ кандидат педагогічних наук, доцент кафедри \\ теорії і практики початкової освіти \\ ДВНЗ «Донбаський державний педагогічний університет» \\ м. Слов'янськ, Україна \\ ORCID ID 0000-0003-3887-4662 \\ viktorenko2210@gmail.com \\ Ірина Федь \\ кандидат педагогічних наук, доцент кафедри \\ теорії і практики початкової освіти \\ ДВНЗ «Донбаський державний педагогічний університет» \\ м. Слов'янськ, Україна \\ irina.e.fed@gmail.com
}

\begin{abstract}
Анотація. Статтю присвячено аналізу можливостей реалізації проєктної технології як найбільш розповсюдженого виду дослідницької роботи учнів в системі позашкільної освіти. Авторками доведено, що проєктне навчання в системі позашкільної освіти стимулює i посилює позитивну мотивацію до навчання, оскільки воно: особистісно-орієнтоване, активізує дидактичні підходи - діяльнісне навчання, колабовативне навчання, мозковий штурм, рольові ігри, евристичне та проблемне навчання, дискусії, командне навчання; дозволяє вчитись на власному досвіді та досвіді інших; приносить задоволення учням, які бачать продукт своєї власної праці. У процесі дослідження доведено, що метод проєктів дає можливість залучати до навчального процесу не тільки оперативну й когнітивну сфери, але й емоційну складову особистості учнів.
\end{abstract}

Ключові слова: позашкільна освіта; метод проєктів; проєктна технологія; освітній процес.

Постановка проблеми в загальному вигляді. Позашкільна освіта $\epsilon$ складовою системи безперервної освіти, визначеної Конституцією України, законами України «Про освіту», «Про позашкільну освіту», і спрямована на розвиток здібностей та обдарувань вихованців, учнів і слухачів, задоволення їх інтересів, духовних запитів і потреб у професійному визначенні.

Професіоналізм педагога: теоретичні й методичні аспекти. - Вип. 16. - Слов’янськ, 2021. 
Одним із пріоритетних завдань сучасної державної політики у сфері позашкільної освіти є поліпшення якості освітніх послуг. У Законі України «Про позашкільну освіту» (2000), Стратегії розвитку позашкільної освіти (2018) підкреслюється особлива роль закладів цієї ланки системи освіти як одного 3 визначальних чинників соціального та професійного самовизначення дітей та молоді.

Нові підходи до проєктування навчально-виховного простору позашкільного навчального закладу, спрямованого на надання дітям і молоді якісної, практично спрямованої освіти, потребують переосмислення виховної парадигми та оновлення змісту освітньої діяльності й передбачають:

- високий рівень підготовки педагога-професіонала, який здатний вибудувати індивідуальну модель роботи 3 кожною дитиною, розвинути його індивідуальні здібності й талант, а також спроможний оперативно приймати стратегічні рішення з огляду на кон'юнктуру освітніх послуг;

- гнучку систему асортименту освітніх послуг, технологій і процесів їх реалізації з урахуванням вимог суспільства;

- надання молоді якісних освітніх послуг, спрямованих на розвиток життєвих компетентностей та які користуються і будуть користуватися попитом на ринку;

- проєктування демократичного управління позашкільним навчальним закладом.

Аналіз останніх досліджень і публікацій. Науково-теоретичною основою навчально-розвивальної та виховної діяльності сучасних позашкільних навчальних закладів є: педагогічна спадщина С. Русової, В. Сухомлинського, К. Ушинського; І. Беха, В. Вербицького, В. Рибалки, І. Лещенко, В. Мачуського, Н. Підлісної, Г. Пустовіта, Л. Сєрих，А. Сиротенка 3 проблем виховання та розвитку особистості в шкільному та позашкільному навчальному процесі, організаційно-педагогічних засад діяльності позашкільних навчальних закладів.

Г. Пустовіт (2010) наголошує, що позашкільна освіта має виявити найближчі перспективи розвитку особистості в різних соціальних й освітньовиховних інститутах, де позашкільні заклади повинні стати центрами мотиваційного розвитку особистості, iï самореалізації i професійного самовизначення (Пустовіт, 2010, с. 28).

Позашкільна робота - це особливим чином організована педагогічна діяльність, що має яскраво виражену специфіку впливу в порівнянні з іншими засобами виховання і визначені переваги, до числа яких належить добровільність участі дітей у позашкільних заняттях, диференціація їх за інтересами i схильностями, індивідуальний підхід тощо. Система позашкільного виховання в 
ідеалі покликана забезпечити можливість кожній дитині у вільний час всебічно розвивати здібності і захоплення.

Отже, актуальність удосконалення змісту позашкільної освіти посилена тим, що ця система визначально орієнтована на вільний вибір особистістю видів i форм діяльності, формування іï особистих уявлень про соціокультурне й соціоприродне середовище, розвиток пізнавальної мотивації та творчих якостей. Тому позашкільну освіту сьогодні слід розглядати як таку, що виявляє найближчі перспективи розвитку особистості в різних соціальних й освітньо-виховних інститутах, де позашкільні навчальні заклади мають стати центрами мотиваційного розвитку особистості, ऑiі самореалізації та професійного самовизначення.

Основний зміст позашкільної освіти на сьогодні передбачає забезпечення процесу соціалізації та саморозвитку особистості з використанням технологій навчання та виховання, реалізації суб'єкт-суб'єктної, партнерської взаємодії педагога і вихованця у навчально-виховному процесі та різнобічній діяльності. Позашкільні заклади продовжують розвиватися як унікальні інститути соціального виховання дитини. Соціальне виховання у позашкільному закладі постає як послідовна реалізація трьох рівнів, які передбачають включення вихованця в діяльність, у процесі якої відбувається виховання особистості, засвоєння знань, соціального досвіду і зразків культури.

Сучасні тенденції розвитку позашкільної освіти вимагають активного впровадження у навчально-виховний процес інтерактивних технологій, які передбачають використання рольових і ділових ігор, моделювання життєвих ситуацій, проведення обговорень, диспутів, що сприятиме розвитку критичного мислення учнів. При цьому роль педагога спрямована на обмін інформацією, власним життєвим досвідом, на активізацію аналізу досягнень i невдач, теоретико-практичний синтез тощо.

Одним із таких інтерактивних методів є метод проєктів, в основі якого практична спрямованість на результат, який можна побачити, осмислити, застосувати на практиці. Проблеми проєктного навчання освітлюються в роботах Т. Бєлявцевої, В. Вербенко, В. Вербицького, І. Вєтрової, І. Срмакова, Т. Лобас, Л. Матвєєвої, Є. Полат, С. Ящука, та інших.

Формулювання цілей статті (постановка завдання). Мета статті полягає у спробі висвітлення можливостей застосування проєктної технології навчання в системі позашкільної освіти.

Результати дослідження. Метод проєктів завжди орієнтований на самостійну діяльність учнів - індивідуальну, парну, групову, яку учні виконують упродовж певного відрізку часу, та спрямований на розв'язання певної 
проблеми, яка передбачає, з одного боку, використання різноманітних методів, засобів навчання, а з іншого, інтегрування знань, умінь із різних галузей науки, техніки, технології, мистецтва. Результати виконаних проєктів повинні бути «відчутними», тобто якщо робота ведеться над теоретичною проблемою, то має бути iї конкретне розв’язання, якщо над практичною - конкретний результат, готовий до впровадження.

Вивчення сучасних підходів до організації проєктної діяльності учнів дало підстави стверджувати, що у рамках класно-урочної системи навчання не повною мірою задовольняються організаційні, ресурсні, матеріально-технічні та інші вимоги до розробки, реалізації та представлення проєкту. Робота над проєктом виходить за рамки уроку, що свідчить про оптимальність організації проєктної діяльності школярів у межах позашкільної освіти для створення зв'язку між навчальними матеріалом заняття, особистими запитами учнів (навчального, пізнавального, ужиткового характеру) та оточуючим середовищем. Це створює сприятливі умови для успішної реалізації особистісно зорієнтованого, компетентністного, діяльнісного підходів у позашкільній освіті.

Аналіз досліджень І. Лещенко (2018), Н. Пустовіт (2010), Л. Сєрих (2018) дозволяє констатувати, що організація проєктної діяльності в практиці позашкільної освіти грунтується на добровільній участі школярів, високому рівні їх самостійності, урахуванні індивідуальних особливостей, запитів і потреб, налагодженні конструктивних міжособистісних стосунків; має пізнавальний, навчальний, виховний, профорієнтаційний, інтеграційний потенціал.

Аналіз робіт сучасних науковців та особистий педагогічний пошук дозволив обгрунтувати проєктну діяльність школярів у практиці позашкільної освіти як складову цілісного педагогічно організованого середовища, що розкриває зв'язок навчального матеріалу з практичним, життєвим досвідом учнів, грунтується на добровільній, самостійній пошуковій активності учнів 3 метою задоволення пізнавальних інтересів шляхом отримання особистісно значущого результату.

Дослідники за кількісним складом учасників визначають індивідуальну, парну, групову та масову форми проєктної діяльності учнів. 3. Возна (2019) наголошує на перевагах групової роботи над проєктом: комплексний характер вирішення проблеми проєкту, вибір учнями сфери діяльності у проєкті за інтересами та здібностями, розвиток комунікативних навичок школярів, формування умінь співпраці, можливість створення різновікових та різнорівневих груп.

Завдяки вищезазначеному, групова позаурочна проєктна діяльність повною мірою ураховує пізнавальні інтереси, майбутні професійні нахили, 
індивідуальні потреби і можливості учнів за рахунок міжпредметного змісту знань та вільного вибору учнями видів діяльності, відображених у розподілі обов'язків (ролей) учасників проєкту. Групова форма організації реалізується у роботі ініціативної проєктної групи та здійсненні гуртової роботи над проєктом, коли у рамках одного проєкту окремі групи учнів вивчають його різні аспекти. Навчання за проєктною технологією в практиці позашкільної освіти надає системності, регламентованості організації проєктної діяльності.

Для досягнення результату учні мають пройти етапи усвідомлення та осмислення проблеми, самостійного розроблення варіантів вирішення, використовуючи наявні та здобуваючи нові знання, прогнозування очікуваних результатів, самооцінки в ході реалізації проєкту, внесення корективів у план дій, аналізу досягнутого, рефлексії.

Окремо необхідно зупинитися на методі проєктів як актуальному методі у практиці позашкільної освіти.

Навчальний проєкт вченими розуміється як особистісно орієнтована технологія та спосіб організації самостійної діяльності учнів, спрямований на вирішення поставлених завдань та мети, передбачає рефлексивну, презентаційну, дослідницьку, пошукову види діяльності учнів, інтегрує в собі проблемний підхід, групові методи.

Навчальний проєкт для учнів створює можливості виконувати особистісно значущу діяльність самостійно, у групі або індивідуально, максимально використовуючи власні можливості. Участь у проєктній діяльності дозволяє учню виявити себе, спробувати власні сили, застосувати знання, презентувати досягнутий результат, відчути себе «корисним».

Навчальний проєкт для вчителя — це інтегративний дидактичний засіб навчання й виховання, що дозволяє розвивати наступні компетенції старшокласника:

- аналізу проблемного поля, формулювання провідної проблеми, постановки завдань;

- визначення цілей та планування діяльності;

- пошуку необхідної інформації, її систематизації й структуризації;

- вибору, освоєння й використання технології, адекватної проблемній ситуації й кінцевому продукту проєктування;

- проведення дослідження (аналізу, синтезу, висуванню гіпотези, деталізації й узагальнення);

- застосування знань, умінь i навичок у різних, у тому числі й нестандартних ситуаціях;

Професіоналізм педагога: теоретичні й методичні аспекти. - Вип. 16. - Слов'янськ, 2021. 
- самоаналізу й рефлексії (самоаналіз успішності й результативності рішення проблеми в рамках проєкту);

- презентації (формування іміджу) діяльності та ії результатів.

Можемо визначити основні вимоги до навчально-дослідницьких проєктів у позашкільній освіті:

1. Наявність значимої для учня проблеми / завдання (дослідницької, інформаційної, практичної), що вимагає інтегрованого знання, дослідницького пошуку іï рішення (наприклад, дослідження теоретичної або практичної проблеми побудови нового технічного об'єкту чи моделі 3 новими властивостями; створення серії доповідей-досліджень за однією проблемою; проблема впливу технічних об'єктів на навколишнє середовище та ін.).

2. Практична, теоретична значимість передбачуваних результатів (наприклад, доповідь у відповідних службах даного регіону по факторах, що впливають на стан навколишнього середовища, тенденціях, що простежуються в розвитку даної проблеми; спільний з партнерами по проєкту випуск газети, альманаху з репортажами з місця подій; план заходів і т.п.).

3. Структурування змістовної частини проєкту (із визначенням поетапних результатів).

4. Самостійна (індивідуальна, парна, групова) діяльність учнів.

5. Використання дослідницьких методів.

У загальному вигляді організація проєктної діяльності учнів включає наступні етапи:

1 етап - занурення в проблему;

2 етап - організація діяльності;

3 етап - здійснення діяльності;

4 етап - презентація результатів, самооцінка й самоаналіз.

Під навчально-дослідницькою діяльністю учнів розуміють діяльність, пов'язану з пошуком рішення дослідницького завдання, яка передбачає наявність основних етапів, характерних для наукового дослідження. Навчальнодослідницька діяльність передбачає самостійне або під керівництва педагога, рішення учнями нової для них проблеми із застосуванням таких елементів дослідження, як висування гіпотези та їі перевірка, збір й самостійний аналіз фактів, формулювання висновків, підтвердження закону або закономірностей.

Незалежно від різних видів навчально-дослідницької діяльності учнів виділяються наступні основні етапи дослідження:

- виявлення протиріччя й постановка проблеми, що вимагає рішення;

- вибір теми дослідження;

- визначення мети і завдань дослідження; 
- визначення методів дослідження;

- збір власного матеріалу за допомогою методів дослідження;

- аналіз і узагальнення зібраного матеріалу;

- власні висновки.

У цілому послідовність організації навчально-дослідницької діяльності учнів може бути представлена в такий спосіб (табл. 1.1).

\section{Таблиия 1.1.}

\section{Послідовність організації навчального дослідження учнів}

\begin{tabular}{|c|c|c|c|}
\hline \multicolumn{4}{|c|}{ Вибір теми дослідження } \\
\hline $\begin{array}{lr}\text { Теми } \quad \text { й } & \text { проблеми } \\
\text { навчальних } & \text { занять, } \\
\text { питання, що виникають } \\
\text { при обговоренні }\end{array}$ & $\begin{array}{lr}\text { Доповіді і } & \text { повідомлення } \\
\text { учнів, } & \text { найцікавіші } \\
\text { проблеми і } & \text { завдання, що } \\
\text { вимагають } & \text { подальшоі } \\
\text { розробки } & \end{array}$ & $\begin{array}{l}\text { Список тем } \\
\text { досліджень, що } \\
\text { рекомендується } \\
\text { педагогом }\end{array}$ & $\begin{array}{ll}\text { Власні питання } \\
\text { та } \\
\text { учнів }\end{array}$ \\
\hline \multicolumn{4}{|c|}{ Шляхи реалізації дослідження } \\
\hline $\begin{array}{l}\text { Вибір } \quad \text { наукового } \\
\text { керівника }\end{array}$ & $\begin{array}{lr}\begin{array}{l}\text { Складання } \\
\text { (проєкту) } \\
\text { роботи }\end{array} & \text { пайбутнану } \\
\end{array}$ & \multicolumn{2}{|c|}{$\begin{array}{l}\text { Застосування методів дослідження } \\
\text { (спостереження, експеримент та ін.) } \\
\text { та збір емпіричного матеріалу }\end{array}$} \\
\hline \multicolumn{4}{|c|}{ Написання роботи } \\
\hline $\begin{array}{l}\text { Аналіз отриманого } \\
\text { матеріалу, } \\
\text { систематизація, } \\
\text { класифікація }\end{array}$ & Синтез результатів & \multicolumn{2}{|c|}{ Узагальнення, висновки } \\
\hline \multicolumn{4}{|c|}{ Перша оцінка роботи } \\
\hline $\begin{array}{l}\text { Перше читання роботи } \\
\text { науковим керівником }\end{array}$ & Консультації & \multicolumn{2}{|c|}{ Презентація задуму дослідження } \\
\hline \multicolumn{4}{|c|}{ Підготовка до презентації роботи } \\
\hline $\begin{array}{l}\text { Редагування } \\
\text { остаточного варіанту } \\
\text { роботи }\end{array}$ & Складання тез & \multicolumn{2}{|c|}{ Оформлення наочного матеріалу } \\
\hline
\end{tabular}

Важливою умовою залучення учнів до дослідницької діяльності $\epsilon$ створення умов для підтримки, впровадження й поширення результатів діяльності.

I. Лещенко (2018) розглядає різні моделі організації навчальнодослідницької діяльності учнів у межах позашкільної освіти.

Модель 1. Мета: не стільки досягнення результату, скільки освоєння самого процесу дослідження. Технологія: учитель ставить проблему й намічає стратегію й тактику іiі рішення, саме рішення має бути знайдене учнем. Модель реалізується як форма організації індивідуальної діяльності учня. 
Модель 2. Мета: розвиток проблемного бачення, стимулювання пошукового мислення. Технологія: учитель ставить проблему, але метод iii рішення учні шукають самостійно. Реалізується як форма організації групової й колективної діяльності учнів під час заняття .

Модель 3. Мета: формування наукового мислення, синтез процесу дослідження і його результатів. Технологія: постановка проблеми, пошук методів iï дослідження й розробка рішення здійснюється учнем самостійно.

Види представлення результатів проєктної діяльності учнів: Web-cайт, відеофільм, відео-кліп, електронна газета, атлас, карта, колекція; мультимедійний продукт, путівник, рекламний проспект, довідник, словник, сценарій, віртуальна екскурсія, щоденник подорожей тощо.

Беручи за основу теоретичні положення та практичний досвід позашкільної освіти, розглянемо, питання класифікації проєктів. Значний внесок у розвиток теорії проєктування робить російська дослідниця Є. Полат (2006). Ïї класифікація проєктів здійснена відповідно до предметно-змістової спрямованості з виокремленням монопредметних (виконуються на заняттях одного предмету, хоча і передбачаються під час використання знань з інших дисциплін) та міжпредметних (виконуються зазвичай у міжпредметного час, передбачають інтеграцію знань 3 декількох предметів та потребують кваліфікованої допомого викладачів-предметників) проєктів. Г. Чайковська (2017) і Н. Кулалаєва (2018) класифікують проєкти відповідно до провідного методу чи діяльності.

Прикладні проєкти, відрізняються чітко визначеним результатом діяльності його учасників (наприклад, проєкт закону, довідкові матеріали, словник, аргументоване пояснення будь-якого явища). Такі проєкти, передбачають грунтовне осмислення структури, розподіл функцій між учасниками, оформлення результатів діяльності, їх подальшу презентацію та зовнішнє рецензування.

Дослідницькі проєкти, що мають на меті організацію діяльності учнів, спрямовану на розв'язання творчих завдань із заздалегідь невідомим результатом та передбачають наявність певних етапів роботи (обгрунтування актуальності теми дослідження, предмету та об'єкту, визначення цілей та завдань, виявлення методів пошуку та джерел інформації, висунення гіпотези, визначення шляхів розв'язання проблеми, збір даних, їх аналіз та синтез, обговорення та оформлення отриманих результатів, виступ з повідомленням чи доповіддю, визначення нових проблем для подальшого аналізу).

Інформащійні проєкти, котрі скеровані на вивчення характеристик будьяких процесів, явищ, об'єктів і передбачають їх аналіз та узагальнення виявлених 
фактів; структура такого проєкту схожа на структуру дослідницького, що часто $є$ основою для їх поєднання.

Рольові проєкти, в яких учасники виконують визначені ролі (літературних персонажів чи вигаданих героїв), зумовлені характерові і змістом проєкту; імітують соціальні чи ділові відносини, ускладнені гіпотетичними ігровими ситуаціями; структура таких проєктів лише окреслюється і залишається відкритою до завершення роботи. Такі проєкти дозволяють не лише отримати нові знання, але й сприяють отриманню певного соціального досвіду.

Творчі проєкти не мають детально опрацьованої структури спільної діяльності учасників, вона розвивається, підпорядковуючись кінцевому результату, прийнятій групою логіці спільної діяльності, інтересам учасників проєкту. Вони заздалегідь домовляються про заплановані результати і форму їх представлення: рукописний журнал, колективний колаж, відеофільм, свято, тощо. Надалі розробляють сценарій фільму, програма свята, макет журналу, альбому, газети.

Ігрові проєкти. Учасники беруть собі визначені ролі, обумовлені характером і змістом проєкту. Це можуть бути як літературні персонажі, так і реальні особистості, імітуються їх соціальні і ділові стосунки, які ускладнюються вигаданими учасниками ситуаціями. Ступінь творчості учнів дуже високий, але провідним видом діяльності все жє гра.

Інформаиійні проєкти. Спрямовані на збирання інформації про якийнебудь об’єкт, явище, на ознайомлення учасників проєкту з цією інформацією, іiі аналіз і узагальнення фактів. Такі проєкти потребують добре продуманої структури, можливості систематичної корекції у ході роботи над проєктом. Структуру такого проєкту можна позначити таким чином: мета проєкту, його актуальність; методи отримання (літературні джерела, засоби масової інформації, бази даних, у тому числі й електронні інтерв’ю, анкетування тощо) та обробки інформації (iї аналіз, узагальнення, зіставлення з відомими фактами, аргументовані висновки); результат (стаття, доповідь, реферат, відеофільм); презентація (публікація, у тому числі в електронній мережі, обговорення у телеконференціi). Такі проєкти можуть бути органічною частиною дослідницьких проєктів, їхнім модулем.

Практико-орієнтовані проєкти. Результат діяльності учасників чітко визначено від самого початку, він орієнтований на соціальні інтереси учасників (документ, програма, рекомендації, проєкт закону, словник, проєкт шкільного саду). Проєкт потребує складання сценарію всієї діяльності його учасників 3 визначенням функцій кожного 3 них. Особливо важливими $є$ організація координаційної роботи у вигляді поетапних обговорень та презентація

Професіоналізм педагога: теоретичні й методичні аспекти. - Вип. 16. - Слов’янськ, 2021. 
одержаних результатів і можливих засобів їх упровадження у практику. Якщо короткотермінові проєкти можуть виконуватися на уроках з одного предмету, то довготермінові проєкти (від одного місяця до року) присвячені доволі великій або декільком пов'язаним проблемам, і відповідно є міждисциплінарними та аналізуються здебільшого в позаурочний час. У реальній практиці здебільшого застосовуються змішані типи проєктів, де, наприклад, поєднуються ознаки предметних і між предметних.

Теми проєктів найчастіше сьогодні стосуються конкретного практичного питання, що є актуальним для реального життя. Разом із тим, це вимагає залучення знань не лише з одного предмету, але й з різних галузей, стимулює систематичне творче мислення, розвиток навичок дослідницької роботи. Саме таким чином досягається природна інтеграція знань. При визначенні методів стимуляції творчої активності учнів необхідно пам'ятати про індивідуальні особливості дітей. Навчально-виховний ефект від використання зазначених методів досягається внаслідок систематичної роботи з учнями 3 вирішення творчих задач, створення творчих проєктів.

Залучення вихованців до проєктної діяльності сприяє розвитку творчості, ініціативи, самостійності, організаторських здібностей, стимулює процес i самовдосконалення, різноманітність мотивів, прагнень, які спонукають учнівську молодь до активної участі в проєктній діяльності, дає можливість самоствердитися, усвідомити себе як потрібну в соціумі особистість, яка важлива й для інших громадян - учителів, батьків, ровесників.

Проєктна діяльність відкриває широкі можливості для вибору ролі в системі взаємин (організатор, учасник, виконавець); вона передбачає активну діяльність кожного, оскільки кінцевий результат залежить від спільних зусиль; сприяє формуванню ціннісних орієнтацій (саме і цій діяльності закладаються умови для усвідомлення особистістю своїх вчинків, дій). Проєктна діяльність $\epsilon$ тією конкретною умовою, яка дає змогу залучати вихованців до розв'язання різних суспільних проблем, формувати нові стосунки, нову систему спілкування, що, в свою чергу, зумовлює нові обов'язки й значно вищі вимоги до діяльності.

Висновки 3 дослідження і перспективи подальших розвідок у цьому напрямі. Отже, на основі аналізу науково-педагогічної літератури можемо висновувати, що сутність проєктної технології навчання полягає в спрямуванні навчально-виховного процесу в практиці позашкільної освіти на виявлення $\mathrm{i}$ задоволення вихованцями особистих пізнавальних запитів, інтересів шляхом планування, реалізації та презентації їх проєктних задумів, що сприяє усвідомленню практичної значущості змісту роботи, забезпечує формування пізнавальної самостійності та активної позиції вихованців у різних сферах 
діяльності. Навчання за проєктною технологією засноване на роботі учнів над навчальним проєктом - системою самостійних організаційних та пізнавальних дій школярів, в основі яких лежить розробка плану, практична реалізація та представлення проєктного задуму, ідеї, завдання, проблеми, стимульовані прагненням учнів отримати значущий для них результат.

\title{
СПИСОК ВИКОРИСТАНИХ ДЖЕРЕЛ:
}

1. Возна, 3. О. (2019). Організація проектної діяльності учнів: навчально-методичний посібник для студентів освітнього ступеня «магістр» денної та заочної форми навчання. Умань : «ВПЦ» Візаві.

2. Довмантович, Н. Г. (2017). Проектна діяльність як засіб формування самоосвітньої компетентності. Науковий вісник Ужгородського наиіонального університету. Серія: Педагогіка. Соціальна робота, (1), 92-95.

3. Закон України «Про позашкільну освіту» (2000). Позашкільна освіта в Україні (нормативно-правові акти). Київ : НЕНЦ, с. 3-32.

4. Костенко, Л. Д. (2021). Цифрові технології в сучасній позашкільній освіті. Pedagogical Sciences: Theory and Practice, 2(1), 226-230. DOI 10.26661/2522-4360-2021-1-2-35.

5. Кулалаєва, Н. (2018). Концептуальні засади проектного професійного навчання у закладах професійної (професійно-технічної) освіти. Професійна педагогіка, (17), 14-21.

6. Купчак, С. Б. (2018). Особливості реалізації проектної технології навчання у початковій школі. Науковий часопис НПУ імені М.П. Драгоманова. Серія 5. Педагогічні науки: реалії та перспективи, (63), 95-98.

7. Лещенко, I. (2018). Створення інноваційного освітнього простору засобами впровадження інноваційних форм та методів навчання і виховання в умовах позашкільного навчального закладу. Витоки педагогічної майстерності, 21, 113-118.

8. Підлісна, Н. П. (2020). Методичні рекомендації щодо впровадження інновацій в управлінській діяльності закладом позашкільної освіти. Традиџійні та інноваиійні підходи до наукових досліджень, 3, 65-66.

9. Полат, Е. (2006). Метод проектов: история и теория вопроса. Школьные технологии, 6, 43-48.

10. Пустовіт, Г. (2010). Позашкільна освіта та виховання крізь призму сьогодення. Рідна школа, 3, 28-32.

11. Сєрих, Л. В. (2018). Методика взаємодії загальноосвітніх та позашкільних навчальних закладів в естетичному вихованні підлітків. Педагогічні науки, 32, 177-184.

12. Стратегія розвитку позашкільної освіти (2018). Ред. проф. О. В. Биковської. Київ: IBЦ АЛКОН. Взято http://enpuir.npu.edu.ua/bitstream/123456789/23320/1/Stratehiia\%20Rozvytku\%20Poz ashkilnoi\%20Osvity.pd

13. Чайковська, Г. (2017). Проектні технології як ефективний засіб формування екологічної культури студентів. Наукові записки Тернопільського наџіонального педагогічного університету імені Володимира Гнатюка. Серія: педагогіка, (3), 106-113.

\section{IMPLEMENTATION OF THE PROJECT LEARNING TECHNOLOGY IN THE SYSTEM OF EXTRACURRICULAR EDUCATION}

\author{
Nadiia Vovk \\ Candidate of Pedagogical Sciences, Associate Professor of the \\ Department of Theory and Practice of Technological and Vocational Education
}

Професіоналізм педагога: теоретичні й методичні аспекти. - Вип. 16. - Слов'янськ, 2021. 
Н. ВОВК, І. ВІКТОРЕНКО, І. ФЕДЬ

Реалізація проєктної технології навчання в системі позашкільної освіти

\title{
SHEI "Donbas State Pedagogical University" \\ Sloviansk, Donetsk region, Ukraine \\ nadiyavovk@ukr.net
}

\author{
Iryna Viktorenko \\ Candidate of Pedagogical Sciences, Associate Professor of Primary \\ Education Theory and Practice Department \\ SHEI "Donbas State Pedagogical University" \\ Sloviansk, Ukraine \\ ORCID ID 0000-0003-3887-4662 \\ viktorenko2210@gmail.com
}

\author{
Iryna Fed \\ Candidate of Pedagogical Sciences, Associate Professor of Primary \\ Education Theory and Practice Department \\ SHEI "Donbas State Pedagogical University" \\ Sloviansk, Ukraine \\ irina.e.fed@gmail.com
}

\begin{abstract}
The article is devoted to the analysis of possibilities of realization of project technology as the most widespread kind of research work of the students in system of out-of-school education. The authors proved that project-based learning in extracurricular education stimulates and enhances positive motivation to learn, because it is: personality-oriented, activates didactic approaches - activity learning, collaborative learning, brainstorming, role-playing games, heuristic and problem-based learning, discussions, team learning; allows students to learn from their own experience and the experience of others; brings pleasure to students who see the product of their own work. In the course of the research it was proved that the project method gives an opportunity to involve in the educational process not only the operational and cognitive spheres, but also the emotional component of the students' personality.

The authors concluded that the essence of project learning technology is to direct the educational process in the practice of extracurricular education to identify and meet students' personal cognitive needs, interests through planning, implementation and presentation of their project ideas, which helps to understand the practical significance of content, provides cognitive independence and active position pupils in various fields of activity.

Project-based learning is based on students' work on a learning project - a system of independent organizational and cognitive actions of students, which is based on the development of a plan, practical implementation and presentation of project ideas, ideas, tasks, problems, stimulated by students' desire to achieve meaningful results.
\end{abstract}

Key words: model extracurricular education; project method; design technology; educational process.

\section{REFERENCES}

1. Vozna, Z. O. (2019). Orhanizatsiia proiektnoi diialnosti uchniv [Organization of project activities of students]. Uman : "VPTs" Vizavi. [in Ukrainian].

2. Dovmantovych, N. H. (2017). Proiektna diialnist yak zasib formuvannia samoosvitnoi kompetentnosti [Project activity as a means of forming self-educational competence.]. Naukovyi visnyk Uzhhorodskoho natsionalnoho universytetu. Seriia: Pedahohika. Sotsialna robota, (1), 92-95. [in Ukrainian].

() ДВНЗ «Донбаський державний педагогічний університет» 
3. Zakon Ukrainy "Pro pozashkilnu osvitu" [Law of Ukraine "On Extracurricular Education"]. (2000). Pozashkilna osvita v Ukraini (normatyvno-pravovi akty). Kyiv: NENTs, s. 332. [in Ukrainian].

4. Kostenko, L. D. (2021). Tsyfrovi tekhnolohii v suchasnii pozashkilnii osviti [Digital technologies in modern extracurricular education]. Pedagogical Sciences: Theory and Practice, 2(1), 226-230. DOI 10.26661/2522-4360-2021-1-2-35. [in Ukrainian].

5. Kulalaieva, N. (2018). Kontseptualni zasady proiektnoho profesiinoho navchannia u zakladakh profesiinoi (profesiino-tekhnichnoi) osvity [Conceptual principles of project vocational training in professional (vocational) education institutions]. Profesiina pedahohika, (17), 14-21. [in Ukrainian].

6. Kupchak, S. B. (2018). Osoblyvosti realizatsii proiektnoi tekhnolohii navchannia u pochatkovii shkoli [Features of realization of project technology of training in primary school]. Naukovyi chasopys NPU imeni M.P. Drahomanova. Seriia 5. Pedahohichni nauky: realii ta perspektyvy, (63), 95-98. [in Ukrainian].

7. Leshchenko, I. (2018). Stvorennia innovatsiinoho osvitnoho prostoru zasobamy vprovadzhennia innovatsiinykh form ta metodiv navchannia i vykhovannia $\mathrm{v}$ umovakh pozashkilnoho navchalnoho zakladu [Creation of innovative educational space by means of introduction of innovative forms and methods of teaching and education in the conditions of out-ofschool educational institution]. Vytoky pedahohichnoi maisternosti, 21, 113-118. [in Ukrainian].

8. Pidlisna, N. P. (2020). Metodychni rekomendatsii shchodo vprovadzhennia innovatsii v upravlinskii diialnosti zakladom pozashkilnoi osvity [Methodical recommendations for the introduction of innovations in the management of out-of-school education]. Tradytsiini ta innovatsiini pidkhody do naukovykh doslidzhen, 3, 65-66. [in Ukrainian].

9. Polat, E. (2006). Metod proektov: istoriia i teoriia voprosa [Project method: history and theory of the issue]. Shkolnye tekhnolohii, 6, 43-48. [in Russian].

10. Pustovit, H. (2010). Pozashkilna osvita ta vykhovannia kriz pryzmu sohodennia [Extracurricular education and upbringing through the prism of the present]. Ridna shkola, 3, 28-32. [in Ukrainian].

11. Sierykh, L. V. (2018). Metodyka vzaiemodii zahalnoosvitnikh ta pozashkilnykh navchalnykh zakladiv $\mathrm{v}$ estetychnomu vykhovanni pidlitkiv [Methods of interaction between secondary and out-of-school educational institutions in the aesthetic education of adolescents]. Pedahohichni nauky, 32, 177-184. [in Ukrainian].

12. Stratehiia rozvytku pozashkilnoi osvity [Strategy for the development of extracurricular education]. (2018). Eds. prof. O.V. Bykovskoi. Kyiv: IVTs ALKON. Retrieved from: http://enpuir.npu.edu.ua/bitstream/123456789/23320/1/Stratehiia\%20Rozvytku\%20Poz ashkilnoi\%20Osvity.pdf [in Ukrainian].

13. Chaikovska, H. (2017). Proiektni tekhnolohii yak efektyvnyi zasib formuvannia ekolohichnoi kultury studentiv [Project technologies as an effective means of forming students' ecological culture]. Naukovi zapysky Ternopilskoho natsionalnoho pedahohichnoho universytetu imeni Volodymyra Hnatiuka. Seriia: pedahohika, (3), 106-113. [in Ukrainian].

Матеріали надійшли до редакції 30.09.2021 р.

Професіоналізм педагога: теоретичні й методичні аспекти. - Вип. 16. - Слов'янськ, 2021. 